\title{
Shear Bond Strengths of Different Adhesive Systems to Biodentine
}

\author{
Mesut Enes Odabaş, ${ }^{1}$ Mehmet Bani, ${ }^{1}$ and Resmiye Ebru Tirali ${ }^{2}$ \\ ${ }^{1}$ Department of Pediatric Dentistry, Faculty of Dentistry, University of Gazi, 8 Cadde, 82 Sokak, 06510 Ankara, Turkey \\ ${ }^{2}$ Department of Pediatric Dentistry, Faculty of Dentistry, University of Başkent, 06490 Ankara, Turkey \\ Correspondence should be addressed to Mesut Enes Odabaş; mesut@gazi.edu.tr
}

Received 5 August 2013; Accepted 5 September 2013

Academic Editors: E. J. Honkala and R. G. Palma-Dibb

Copyright ( 2013 Mesut Enes Odabaş et al. This is an open access article distributed under the Creative Commons Attribution License, which permits unrestricted use, distribution, and reproduction in any medium, provided the original work is properly cited.

The aim of this study was to measure the shear bond strength of different adhesive systems to Biodentine with different time intervals. Eighty specimens of Biodentine were prepared and divided into 8 groups. After 12 minutes, 40 samples were randomly selected and divided into 4 groups of 10 each: group 1: (etch-and-rinse adhesive system) Prime \& Bond NT; group 2: (2-step selfetch adhesive system) Clearfil SE Bond; group 3: (1-step self-etch adhesive systems) Clearfil $S^{3}$ Bond; group 4: control (no adhesive). After the application of adhesive systems, composite resin was applied over Biodentine. This procedure was repeated 24 hours after mixing additional 40 samples, respectively. Shear bond strengths were measured using a universal testing machine, and the data were subjected to 1-way analysis of variance and Scheffé post hoc test. No significant differences were found between all of the adhesive groups at the same time intervals (12 minutes and 24 hours) $(P>.05)$. Among the two time intervals, the lowest value was obtained for group 1 (etch-and-rinse adhesive) at a 12-minute period, and the highest was obtained for group 2 (two-step self-etch adhesive) at a 24-hour period. The placement of composite resin used with self-etch adhesive systems over Biodentine showed better shear bond strength.

\section{Introduction}

Mineral Trioxide Aggregate (MTA) has rapidly gained acceptance in dentistry since its introduction in 1993 by Torabinejad [1]. However, MTA displays important limitations such as extending time, difficult handling properties, and discoloration potential of dental tissue $[2,3]$. Recently, Biodentine (Septodont, Saint-Maur-des-Fossés, France) is a new tricalcium silicate-based restorative material has been introduced. The main component of Biodentine powder is tricalcium silicate, with the addition of calcium carbonate and zirconium oxide. The liquid is a solution of calcium chloride with a water-reducing agent. The addition of calcium chloride results in shorter setting time, as it also accelerates the rate of early strength development. Thus, the main advantages of Biodentine over MTA are its greater viscosity and its shorter setting time (12 min approximately).

Recently, promising biological properties have been reported for Biodentine on human pulp fibroblast cultures and on the dental pulp in an entire human tooth culture model $[4,5]$. It has been demonstrated that Biodentine induced an effective dentinal repair when applied directly to mechanically exposed rat pulps [6]. In addition, Nowicka et al. [7] evaluated the clinical, radiographical, and histologic responses of the pulp-dentin complex after direct capping with Biodentine and MTA in human teeth. They found similar efficacy in the clinical setting and suggested that Biodentine may be considered an alternative to MTA in pulpcapping treatment during vital pulp therapy.

Biodentine is recommended for use as a dentine substitute under resin composite restorations and an endodontic repair material because of its biocompatibility, bioactivity, and biomineralization properties $[4,5]$. However, the potential of restorative materials to attach Biodentine is not well known. The purpose of this study was to evaluate the shear bond strength of 3 different adhesive systems (etch-and-rinse adhesive, two-step self-etch adhesive, and one-step self-etch adhesive systems) to Biodentine. 
TABLE 1: Materials used in the study.

\begin{tabular}{|c|c|c|}
\hline Material & Composition & Steps of application \\
\hline $\begin{array}{l}\text { Biodentine (Septodont, } \\
\text { Saint-Maur-des-Fossés Cedex, } \\
\text { France) }\end{array}$ & $\begin{array}{l}\text { Powder } \\
\text { Tricalcium silicate, dicalcium silicate, calcium carbonate and } \\
\text { oxide, iron oxide, and zirconium oxide } \\
\text { Liquid } \\
\text { Calcium chloride and hydrosoluble polymer }\end{array}$ & $\begin{array}{l}\text { Five doses liquid and powder } \\
\text { supplied for } 30 \mathrm{~s} \text { with a mixed } \\
\text { amalgamator }\end{array}$ \\
\hline $\begin{array}{l}\text { Composite (Clearfil Majesty, } \\
\text { Kuraray Noritake Dental Inc., } \\
\text { Okayama, Japan) }\end{array}$ & $\begin{array}{l}\text { Silaned barium glass filler, prepolymerized organic filler, bisphenol } \\
\text { A-glycidyl methacrylate (bis-GMA), hydrophobic aromatic } \\
\text { dimethacrylate, and dicamphorquinone }\end{array}$ & Light-cure for $20 \mathrm{~s}$ \\
\hline $\begin{array}{l}\text { Prime \& Bond NT } \\
\text { (Caulk/Dentsply } \\
\text { International Inc., } \\
\text { Milford, DE, USA) }\end{array}$ & $\begin{array}{l}\text { Di- and trimethacrylate resin, PENTA, functionalized } \\
\text { amorphous silica, photoinitiators, stabilizers, cetylamine, } \\
\text { hydrofluoride, and acetone }\end{array}$ & $\begin{array}{l}\text { (1) Apply } 35 \% \text { phosphoric. } \\
\text { acid etchant for } 15 \text { s. } \\
\text { (2) Rinse and blot-dry. } \\
\text { (3) Apply bond. } \\
\text { (4) Allow gentle air stream. } \\
\text { (5) Light-cure for } 10 \mathrm{s.}\end{array}$ \\
\hline $\begin{array}{l}\text { Clearfil SE Bond (Kuraray } \\
\text { Noritake Dental Inc, Okayama, } \\
\text { Japan) }\end{array}$ & $\begin{array}{l}\text { Primer } \\
\text { 10-Methacryloyloxydecyl dihydrogen phosphate (MDP), HEMA, } \\
\text { hydrophilic aliphatic dimethacrylate, dicamphoroquinone, } \\
\text { N-diethyl-p-toluidine, and water } \\
\text { Bond } \\
\text { 10-Methacryloyloxydecyldihy drogenphosphate (MDP), bisphenol } \\
\text { A-glycidyl methacrylate (bis-GMA), HEMA, hydrophobic } \\
\text { aliphatic dimethacrylate, dicamphoroquinone, } \\
\text { N-diethyl-p-toluidine, and colloidal silica }\end{array}$ & $\begin{array}{l}\text { (1) Apply primer for } 20 \mathrm{~s} \text {. } \\
\text { (2) Dry with mild air for } 5 \mathrm{~s} \text {. } \\
\text { (3) Apply bond for } 10 \mathrm{~s} \text {. } \\
\text { (4) Apply air flow gently } \\
\text { (5) Light-cure for } 10 \mathrm{~s} \text {. }\end{array}$ \\
\hline $\begin{array}{l}\text { Clearfil } S^{3} \text { Bond (Kuraray } \\
\text { Noritake Dental Inc, Okayama, } \\
\text { Japan) }\end{array}$ & $\begin{array}{l}\text { 10-Methacryloyloxydecyldihy drogenphosphate (MDP), bisphenol } \\
\text { A-glycidyl methacrylate (bis-GMA), HEMA, hydrophobic } \\
\text { dimethacrylates, dicamphoroquinone, ethanol, water, and } \\
\text { silanated colloidal silica }\end{array}$ & $\begin{array}{l}\text { (1) Apply bond for } 10 \mathrm{~s} \text {. } \\
\text { (2) Dry with mild air for } 5 \mathrm{~s} \text {. } \\
\text { (3) Light-cure for } 10 \mathrm{~s} \text {. }\end{array}$ \\
\hline
\end{tabular}

\section{Materials and Methods}

Three commercial adhesive systems, (etch-and-rinse adhesive system) Prime \& Bond NT, (two-step self-etch adhesive system) Clearfil SE Bond, and (one-step self-etch adhesive systems) Clearfil $S^{3}$ Bond, were tested in this study and applied as recommended by the manufacturers. The materials used are listed in Table 1.

2.1. Specimen Fabrication. A total of 80 acrylic blocks containing a central hole with a $4 \mathrm{~mm}$ diameter and a $2 \mathrm{~mm}$ height were prepared. Biodentine was mixed according to the manufacturer's instructions. The acrylic blocks were fully filled with Biodentine. Then, the specimens were stored at $37^{\circ} \mathrm{C}$ with $100 \%$ humidity for 12 minutes and 24 hours to encourage setting.

After 12 minutes, 40 samples were randomly selected and divided into 4 groups of 10 each: group 1: (etch-and-rinse adhesive system) Prime \& Bond NT; group 2: (two-step selfetch adhesive system) Clearfil SE Bond; group 3: (one-step self-etch adhesive systems) Clearfil $\mathrm{S}^{3}$ Bond; group 4: control (no adhesive). In groups 1, 2, and 3, the corresponding adhesive system was applied over Biodentine according to the manufacturer's instructions (Table 1), whereas in group 4, no adhesive system was applied. A composite material (Clearfil Mejesty, Kuraray Noritake Dental Inc, Okayama, Japan) was applied into a cylindrical shaped plastic matrix with an internal diameter of $2 \mathrm{~mm}$ and a height of $2 \mathrm{~mm}$. Light curing was administered with a light-emitting diode light-curing unit (Elipar FreeLight 2: 3M ESPE, St Paul, MN, USA) with an intensity of $1,200 \mathrm{mV} / \mathrm{cm}^{2}$ for 20 seconds. This procedure was repeated at 24 hours after mixing additional 40 samples, respectively.

2.2. Shear Bond Strength Test. The polymerized specimens were stored in $100 \%$ relative humidity at $37^{\circ} \mathrm{C}$ for 24 hours. For shear bond strength testing, the specimens were secured in a holder placed on the platen of the testing machine and then sheared with a knife-edge blade on a universal testing machine (Lloyd LRX: Lloyd Instruments, Fareham, Hants, $\mathrm{UK}$ ) at a crosshead speed of $1.0 \mathrm{~mm} / \mathrm{min}$. Shear bond strength in MPa was calculated by dividing the peak load at failure with the specimen surface area.

Fracture Analysis. Fractured test specimens were examined under a stereomicroscope at a magnification of $\times 25$ (Stemi 2000C: Carl Zeiss, Gottingen, Germany). Specimen fractures were classified as follows: cohesive failure exclusively within Biodentine, cohesive failure exclusively within restorative material, adhesive failure that occurred at the Biodentinerestorative material interface, or mixed failure when 2 modes of failure happened simultaneously. Fracture analysis was performed by a single observer who was completely uninformed about the experimental groups. 
2.3. Statistical Analysis. One-way analysis of variance was used to detect differences in bond strength among the experimental groups. Post hoc comparisons were performed using the Scheffé test.

\section{Results}

The mean values and standard deviations of shear bond strengths are given in Table 2.

When shear bond strengths of adhesive systems were compared, no significant differences were found between group 1 (etch-and-rinse adhesive), group 2 (two-step self-etch adhesive), and group 3 (one-step self-etch adhesive) at the same time intervals $(P>.05)$.

Among 2 time intervals, the bond strength of group 2 (two-step self-etch adhesive) at a 24-hour period presented significantly higher bond strength values $(19,559 \mathrm{MPa})$ than group 1 (etch-and-rinse adhesive) and group 4 (control) at 12minute period $(P<.05)$.

Table 3 shows the fracture modes of the experimental groups. Most of the observed modes of failure were cohesive in Biodentine and adhesive failure. No specimens failed cohesively within composite resin.

\section{Discussion}

Because Biodentine is recommended for use as a dentine substitute under restorations, the bond strength between restorative materials and Biodentine is important for the quality of filling. In this study, the bond strength of a resin composite when bonded to Biodentine with 3 different adhesive systems (i.e., etch-and-rinse adhesive, two-step self-etch adhesive, and one-step self-etch adhesive systems) was evaluated at 2 time intervals ( $12 \mathrm{~min}$ and $24 \mathrm{~h}$ ). We found that the mean bond strength values ranged from 9,127 to 19,559 MPa. The lowest value was obtained for group 1 (etch-and-rinse adhesive) at a 12-minute period, and the highest was obtained for group 2 (two-step self-etch adhesive) at a 24-hour period. Failure analysis showed adhesive, cohesive, and/or mixed fractures, depending on the adhesive tested. In this study, a general trend was observed; specimens that presented with lower bond strength failed more at composite resin and Biodentine interface (adhesive). On the other hand, specimens with higher bond strength failed more cohesively in Biodentine.

Tricalcium silicate is one of the main constituents of MTA. Tricalcium silicate is used as a bone cement [7] and also as an endodontic material [8]. This material is synthesized in the laboratory from high purity raw materials unlike Portland cements in MTA. It has been demonstrated that pure tricalcium silicate is a suitable replacement for the cementitious component in MTA due to their similar composition and bioactivity [9]. Tricalcium silicate cement has been found to have shorter setting time than MTA and good injectability and bioactivity [10]. One such formulation is Biodentine (Septodont) which was developed as dentin replacement material.
TABLE 2: Mean shear bond strength values of adhesives (MPa) to Biodentine.

\begin{tabular}{lccc}
\hline \multirow{2}{*}{ Composite } & $N$ & \multicolumn{2}{c}{ Mean \pm SD } \\
& & $12 \mathrm{~min}$ & $24 \mathrm{~h}$ \\
\hline Group 1: Prime \& Bond NT 10 & $9.127 \pm 3.161^{\mathrm{a}}$ & $15.990 \pm 3.409^{\mathrm{a}, \mathrm{c}}$ \\
Group 2: Clearfil SE Bond & 10 & $16.903 \pm 8.112^{\mathrm{a}, \mathrm{c}}$ & $19.559 \pm 7.582^{\mathrm{c}}$ \\
Group 3: Clearfil S ${ }^{3}$ Bond & 10 & $11.057 \pm 3.850^{\mathrm{a}, \mathrm{c}}$ & $15.193 \pm 3.344^{\mathrm{a}, \mathrm{c}}$ \\
Group 4: Control & 10 & $1.600 \pm 0.512^{\mathrm{b}}$ & $1.737 \pm 0.434^{\mathrm{b}}$ \\
\hline
\end{tabular}

Different superscript letters indicate significant differences by one-way ANOVA and post hoc Scheffé test within the same time interval or at different time intervals $(P>.05)$.

There are no studies evaluating the bond strength of restorative materials when bonded to Biodentine with adhesive systems for the purpose of outcome comparison. However, tricalcium silicate is the main component of MTA [11]; the outcomes of this study could be compared with earlier studies about MTA.

Tunç et al. [12] evaluated the bond strength of a composite and a compomer to white MTA using etch-and-rinse adhesive (Single Bond) and one-step self-etch adhesive (Prompt LPop). Different from our findings, they found etch-and-rinse adhesive systems bonded to white MTA significantly more strongly than and one-step self-etch adhesive systems in both composite and compomer materials. Bayrak et al. [13] also found that etch-and-rinse adhesive systems exhibited higher shear bond strength than self-etch adhesive systems. However, Neelakantan et al. [14] found that one-step selfetch adhesive (Clearfil $\mathrm{S}^{3}$ Bond) demonstrated higher bond strength to white MTA than did the two-step self-etch adhesive (AdheSE) and the etch-and-rinse adhesive systems (Prime \& Bond NT) immediately and 24 hours after fabrication. Researchers have not reached a consensus on appropriate adhesive systems over MTA yet.

In this study, the highest bond strength value was obtained with self-etch adhesive systems. There is controversy concerning the efficacy of self-etch systems. Some investigations show that they provide dentin bond strength comparable with that obtained with etch-and-rinse system [15-18], whereas others have observed significantly lower bond strengths [19-22]. Amongst the self-etch adhesives, the results of this study revealed that two-step self-etch adhesive system (Clearfil SE Bond) exhibited higher shear bond strength than one-step self-etch adhesive system (Clearfil $S^{3}$ Bond). This result was in agreement with those of previous studies which found that the bond strengths of two-step selfetch adhesives were higher than those of one-step self-etch adhesives [23-26].

\section{Conclusions}

This in vitro study found no statistically significant differences between all the three adhesive systems at each of the 2 time intervals. However, Biodentine has shorter setting time than MTA (12 min); the highest bond strength value was obtained for two-step self-etch adhesive at a 24 -hour period. 
TABLE 3: Fracture modes of thespecimens after shear bond test bond.

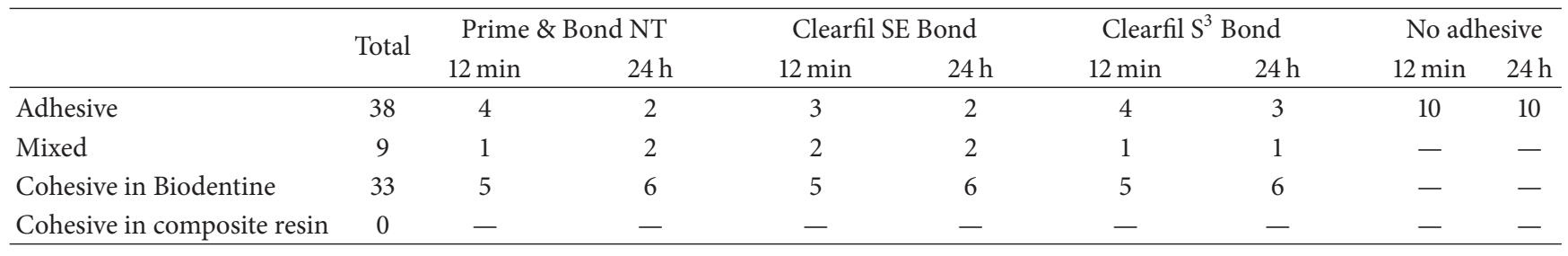

On the other hand, because of the variations in the composition of different resin composites and adhesive systems, different results could be achieved. The adhesive system did not affect the bond strength of Biodentine. Further investigations are needed for better understanding of the adhesion mechanism of adhesive systems to Biodentine.

\section{Conflict of Interests}

The authors deny any conflict of interests related to this study.

\section{References}

[1] S.-J. Lee, M. Monsef, and M. Torabinejad, "Sealing ability of a mineral trioxide aggregate for repair of lateral root perforations," Journal of Endodontics, vol. 19, no. 11, pp. 541-544, 1993.

[2] M. Parirokh and M. Torabinejad, "Mineral trioxide aggregate: a comprehensive literature review-part I: chemical, physical, and antibacterial properties," Journal of Endodontics, vol. 36, no. 1, pp. 16-27, 2010.

[3] T. Dammaschke, H. U. V. Gerth, H. Züchner, and E. Schäfer, "Chemical and physical surface and bulk material characterization of white ProRoot MTA and two Portland cements," Dental Materials, vol. 21, no. 8, pp. 731-738, 2005.

[4] P. Laurent, J. Camps, M. De Méo, J. Déjou, and I. About, "Induction of specific cell responses to a $\mathrm{Ca} 3 \mathrm{SiO} 5$-based posterior restorative material," Dental Materials, vol. 24, no. 11, pp. 14861494, 2008.

[5] P. Laurent, J. Camps, and I. About, "BiodentineTM induces TGF- $\beta 1$ release from human pulp cells and early dental pulp mineralization," International Endodontic Journal, vol. 45, no. 5, pp. 439-448, 2012.

[6] X. V. Tran, C. Gorin, C. Willig et al., "Effect of a calcium-silicatebased restorative cement on pulp repair," Journal of Dental Research, vol. 91, no. 12, pp. 1166-1171, 2012.

[7] A. Nowicka, M. Lipski, M. Parafiniuk et al., "Response of human dental pulp capped with biodentine and mineral trioxide aggregate," Journal of Endodontics, vol. 39, no. 6, pp. 743-747, 2013.

[8] X. Wang, H. Sun, and J. Chang, "Characterization of $\mathrm{Ca}_{3} \mathrm{SiO}_{5} / \mathrm{CaCl}_{2}$ composite cement for dental application," Dental Materials, vol. 24, no. 1, pp. 74-82, 2008.

[9] C.-C. Chen, C.-C. Ho, C.-H. David Chen, and S.-J. Ding, "Physicochemical properties of calcium silicate cements for endodontic treatment," Journal of Endodontics, vol. 35, no. 9, pp. 12881291, 2009.

[10] W. Zhao, J. Wang, W. Zhai, Z. Wang, and J. Chang, "The selfsetting properties and in vitro bioactivity of tricalcium silicate," Biomaterials, vol. 26, no. 31, pp. 6113-6121, 2005.
[11] J. Camilleri, "The physical properties of accelerated Portland cement for endodontic use," International Endodontic Journal, vol. 41, no. 2, pp. 151-157, 2008.

[12] E. Ş. Tunç, I. Ş. Ş. Sönmez, Ş. Bayrak, and T. Eǧilmez, “The Evaluation of Bond Strength of a Composite and a Compomer to White Mineral Trioxide Aggregate with Two Different Bonding Systems," Journal of Endodontics, vol. 34, no. 5, pp. 603-605, 2008.

[13] Ş. Bayrak, E. Ş. Tunç, I. Şaroğlu, and T. Eğilmez, "Shear bond strengths of different adhesive systems to white mineral trioxide aggregate," Dental Materials Journal, vol. 28, no. 1, pp. 62-67, 2009.

[14] P. Neelakantan, D. Grotra, C. V. Subbarao, and F. Garcia-Godoy, "The shear bond strength of resin-based composite to white mineral trioxide aggregate," The Journal of American Dental Association, vol. 143, no. 8, pp. e40-e45, 2012.

[15] M. A. P. Borges, I. C. Matos, and K. R. H. C. Dias, "Influence of two self-etching primer systems on enamel adhesion," Brazilian Dental Journal, vol. 18, no. 2, pp. 113-118, 2007.

[16] R. W. Arnold, E. C. Combe, and J. H. Warford Jr., "Bonding of stainless steel brackets to enamel with a new self-etching primer," American Journal of Orthodontics and Dentofacial Orthopedics, vol. 122, no. 3, pp. 274-276, 2002.

[17] V. Cacciafesta, M. F. Sfondrini, M. De Angelis, A. Scribante, and C. Klersy, "Effect of water and saliva contamination on shear bond strength of brackets bonded with conventional, hydrophilic, and self-etching primers," American Journal of Orthodontics and Dentofacial Orthopedics, vol. 123, no. 6, pp. 633-640, 2003.

[18] J. C. Dorminey, W. J. Dunn, and L. J. Taloumis, "Shear bond strength of orthodontic brackets bonded with a modified 1-step etchant-and-primer technique," American Journal of Orthodontics and Dentofacial Orthopedics, vol. 124, no. 4, pp. 410-413, 2003.

[19] S. E. Bishara, L. VonWald, J. F. Laffoon, and J. J. Warren, "Effect of a self-etch primer/adhesive on the shear bond strength of orthodontic brackets," American Journal of Orthodontics and Dentofacial Orthopedics, vol. 119, no. 6, pp. 621-624, 2001.

[20] S. E. Bishara, R. Ajlouni, J. F. Laffoon, and J. J. Warren, "Effect of a Fluoride-Releasing Self-Etch Acidic Primer on the Shear Bond Strength of Orthodontic Brackets," Angle Orthodontist, vol. 72, no. 3, pp. 199-202, 2002.

[21] R. Yamada, T. Hayakawa, and K. Kasai, "Effect of using selfetching primer for bonding orthodontic brackets," Angle Orthodontist, vol. 72, no. 6, pp. 558-564, 2002.

[22] I. L. Zeppieri, C.-H. Chung, and F. K. Mante, "Effect of saliva on shear bond strength of an orthodontic adhesive used with moisture-insensitive and self-etching primers," American Journal of Orthodontics and Dentofacial Orthopedics, vol. 124, no. 4, pp. 414-419, 2003. 
[23] S. Bouillaguet, P. Gysi, J. C. Wataha et al., "Bond strength of composite to dentin using conventional, one-step, and selfetching adhesive systems," Journal of Dentistry, vol. 29, no. 1, pp. 55-61, 2001.

[24] C. Kaaden, J. M. Powers, K.-H. Friedl, and G. Schmalz, "Bond strength of self-etching adhesives to dental hard tissues," Clinical oral investigations, vol. 6, no. 3, pp. 155-160, 2002.

[25] J. De Munck, B. Van Meerbeek, I. Satoshi et al., "Microtensile bond strengths of one- and two-step self-etch adhesives to burcut enamel and dentin," American Journal of Dentistry, vol. 16, no. 6, pp. 414-420, 2003.

[26] S. Inoue, M. A. Vargas, Y. Abe et al., "Microtensile bond strength of eleven contemporary adhesives to dentin," Journal of Adhesive Dentistry, vol. 3, no. 3, pp. 237-245, 2001. 


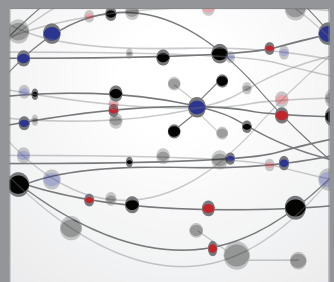

The Scientific World Journal
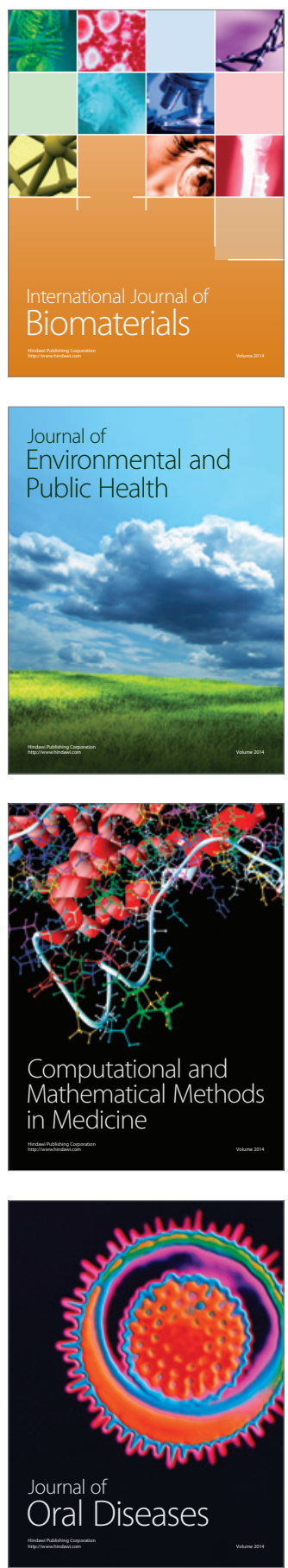
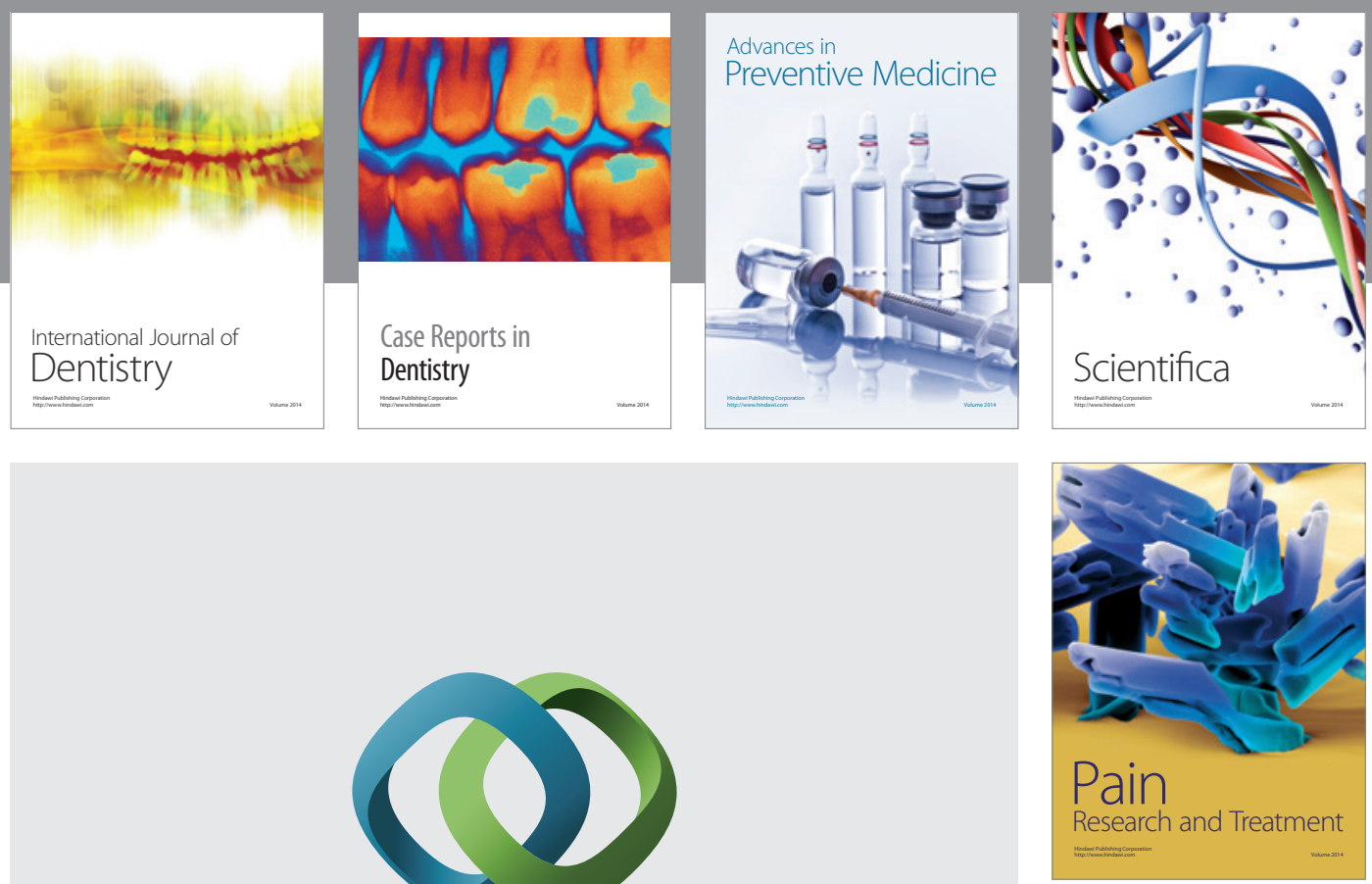

\section{Hindawi}

Submit your manuscripts at

http://www.hindawi.com
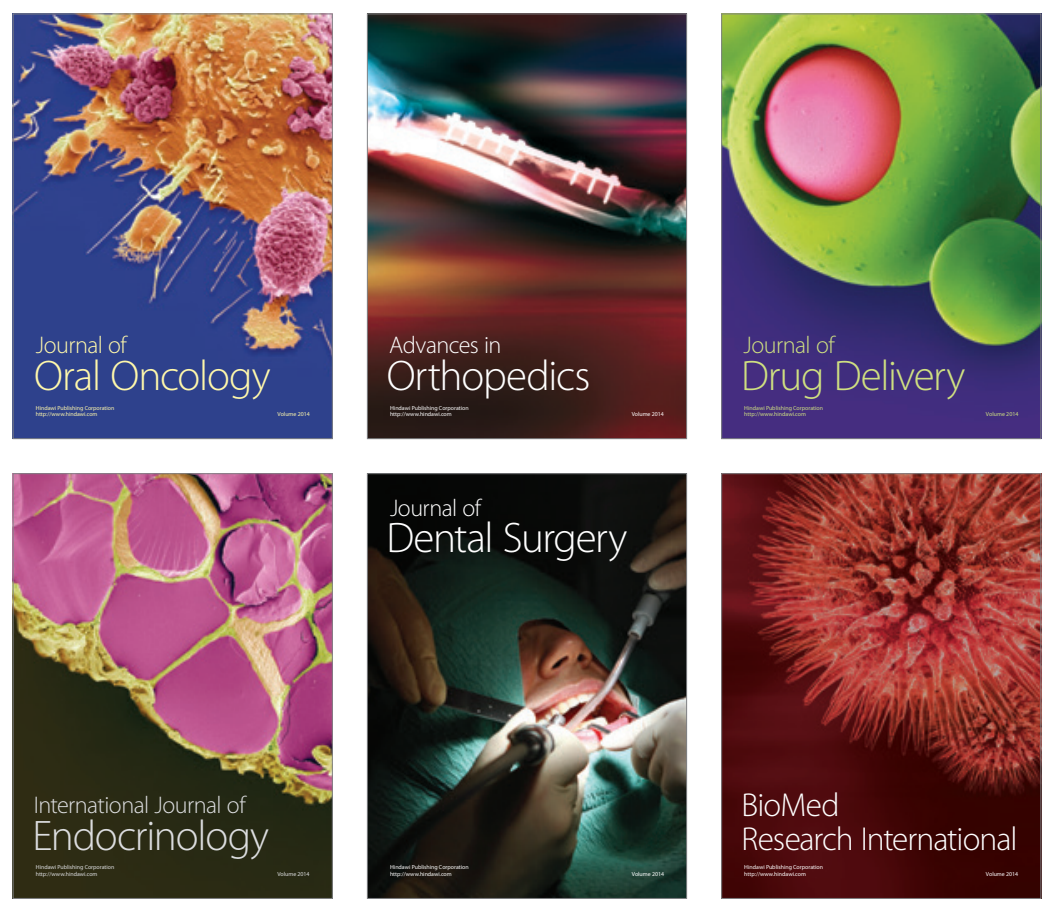

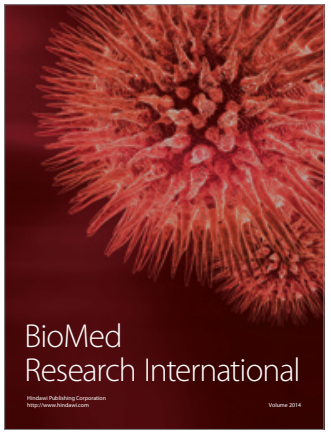

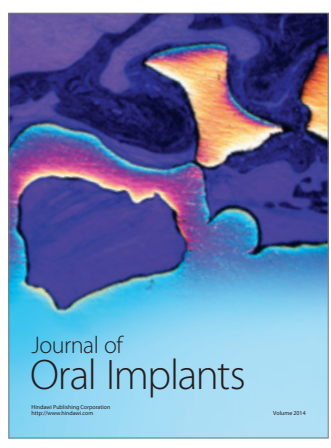
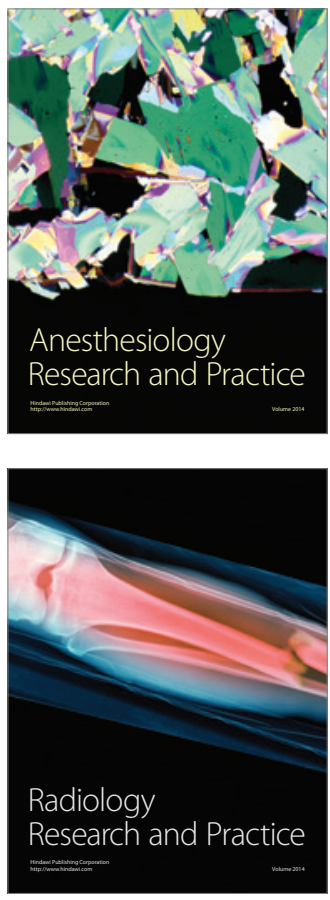